\title{
PENGARUH PROFITABILITAS DAN SOLVABILITAS TERHADAP HARGA SAHAM PERUSAHAAN TERINDEKS LQ45 DI BEI
}

\author{
Yuniar Fitriyani ${ }^{1}$ \\ Institut Teknologi dan Bisnis Asia Malang ${ }^{1}$ \\ Email : yuniar.fitriani@ asia.ac.id ${ }^{1}$
}

\begin{abstract}
The purpose of this study was to analyze the effect of independent variables, profitability proxied by Return On Equity (ROE) and solvency proxied by Debt to Assets Ratio (DAR) on the dependent variable, namely stock prices. The population in this study were 45 companies in the LQ45 category listed on the Indonesia Stock Exchange. Sampling in this study using purposive sampling method, namely as many as 31 companies that are consistently indexed LQ45 on the Indonesia Stock Exchange (IDX) during the 2015-2019 period with the amount of data processed after the outlier process as many as 129 samples. The analysis test model used in this hypothesis is multiple linear regression analysis. The results showed that profitability (ROE) had no effect on stock prices, solvency (DAR) had no effect on stock prices, and simultaneously (ROE) and solvency (DAR) had no effect on company stock prices.
\end{abstract}

Keywords: Stock Price, Return on Equity (ROE), Debt to Assets Ratio (DAR)

\section{Pendahuluan}

Pasar modal adalah tempat pertemuan antara penawaran dengan permintaan surat berharga. Bursa Efek merupakan tempat bertemunya pelaku pasar baik individu atau perusahaan yang mempunyai kelebihan dana (surplus fund) melakukan investasi dalam surat berharga yang ditawarkan oleh perusahaan penerbit saham (Sunariyah, 2011). Peran penting pasar modal dalam perekonomian suatu negara adalah sebagai sarana pendanaan usaha bagi perusahaan untuk mendapatkan dana dari investor. Masyarakat dapat berinvestasi pada instrument keuangan sesuai dengan kriteria dan resiko yang dipilih, misalnya saham. Bagi emiten (perusahaan penerbit saham), dana yang diperoleh dari investor dapat digunakan untuk penambahan modal kerja, pengembangan usaha, dan ekspansi.

Saham yang bagus bagi para investor adalah saham yang memiliki nilai 
fundamental perusahaan yang baik, banyak diperdagangkan, dan harganya selalu mengalami kenaikan (Frans Napitu, 2018). Ini berarti bahwa harga saham dapat menunjukkan bagaimana nilai perusahaan di mata investor. Semakin tinggi harga saham, maka semakin tinggi nilai perusahaan tersebut dan begitu pula sebaliknya. Bila harga saham yang tinggi, dapat berakibat kemampuan investor menjadi berkurang dalam membeli saham, sebaliknya bila harga saham rendah investor akan membaca perusahaan tidak mempunyai kinerja yang bagus (Hartono, 2016).

Indeks harga saham merupakan ringkasan informasi kinerja pasar saham dalam suatu indeks dan indikator yang menggambarkan pergerakan harga-harga saham. Terdapat sebelas indeks di Bursa Efek Indonesia, yaitu indeks individual, indeks harga saham sektoral, indeks harga saham gabungan (IHSG), indeks LQ45, indeks syariah, indeks papan utama, indeks papan pengembangan, indeks PEFINDO25, indeks SRI-KEHATI, indeks BISNIS-27 dan indeks kompas 100.

Indeks LQ45 merupakan 45 saham paling likuid di pasar modal, memiliki kapitalisasi pasar terbesar, prospek pertumbuhan yang tinggi dengan fundamental kinerja yang baik, serta beberapa kriteria lainnya. Bursa Efek Indonesia selalu melakukan evaluasi setiap 6 bulan sekali yaitu Februari-Juli dan Agustus-Januari terhadap saham LQ45 sehingga yang terdaftar dalam indeks LQ-45 selalu berubah.

Dalam menentukan pilihan investasi sahamnya, investor sering menggunakan analisis fundamental yaitu melihat laporan keuangan perusahaan, karena dari laporan keuangan perusahaan dapat diperkirakan keadaan dan posisi perusahaan. Analisis fundamental digunakan untuk menghitung nilai intrinsik dari suatu saham dengan menggunakan data atau rasio-rasio keuangan perusahaan. Rasio keuangan perusahaan terdiri dari 5 (lima) bagian, yaitu ; (1) rasio leverage mengukur sejauh mana perusahaan dibiayai dari dana pinjaman, (2) rasio likuiditas mengukur kemampuan perusahaan untuk memenuhi kewajiban lancarnya, (3) rasio profitabilitas mengukur kemampuan perusahaan dalam mendapatkan laba, (4) rasio aktivitas mengukur seberapa efektif perusahaan memanfaatkan sumber dananya, dan (5) rasio pasar sebagai acuan untuk mengukur pengakuan pasar yaitu para investor dalam menilai kondisi keuangan perusahaan (Wiagustini, 2014). Analisis fundamental yang dikaji dalam penelitian ini adalah yaitu rasio profitabilitas yang 
diproksikan oleh Return on Equity (ROE) dan rasio solvabilitas yang diproksikan oleh Debt to Asset Ratio (DAR).

Return on Equity (ROE) merupakan tingkat kemampuan perusahaan dalam menghasilkan laba setelah pajak dengan menggunakan modal sendiri yang dimiliki perusahaan (Sudana, 2011). Berdasar teori ini, ROE sebagai salah satu indikator untuk menentukan kelayakan suatu investasi mengandung pengertian bahwa semakin besar persentase return on equity maka semakin baik keadaan perusahaan tersebut, sehingga dapat meningkatkan kepercayaan dan minat calon investor untuk menanamkan modalnya. Investor di pasar modal akan merespon positif karena pada kondisi yang seperti itulah harga saham di pasar modal akan bergerak naik. Respon positif menunjukkan adanya kenaikan jumlah permintaan saham. Penelitian yang dilakukan oleh Anindita (2017), Ridwan \& Diyani (2018) dan Firdausia \& Ariyanto (2018) menyatakan bahwa ROE berpengaruh signifikan terhadap harga saham. Namun penelitian-penelitian tersebut kemudian dibantah oleh hasil penelitian Putri (2018), Vanesa et al., (2020) serta Saputri \& Arilyn (2020) yang mengemukakan bahwa ROE tidak berpengaruh terhadap harga saham.

Debt to Asset Ratio (DAR) merupakan rasio untuk mengukur perbandingan antara total utang dengan total aktiva. Dengan kata lain, rasio ini menghitung seberapa besar aktiva perusahaan dibiayai oleh utang atau seberapa besar utang perusahaan berpengaruh terhadap pengelolaan aktiva (Kasmir, 2014). Menurut Sartono (2008) semakin tinggi Debt Ratio maka investor akan menghadapi resiko yang lebih tinggi. Investor akan meminta tingkat keuntungan yang semakin tinggi. Rasio DAR yang tinggi menunjukkan jumlah utang yang lebih tinggi daripada aktiva perusahaan. Investor di pasar modal akan merespon negatif karena pada kondisi yang seperti itulah harga saham di pasar modal akan bergerak turun. Respon negatif menunjukkan adanya penurunan jumlah permintaan saham. Penelitian yang dilakukan oleh Firdausia \& Ariyanto (2018), Ramadhana \& Sjahruddin (2018) ,Ridwan \& Diyani (2018), Ilman (2019) menunjukkan bahwa DAR berpengaruh positif terhadap harga saham. Namun penelitian tersebut tidak sesuai dengan hasil penelitian Anindita (2017), Putri (2018), Ridwan \& Diyani (2018), Nehe (2019), Sitompul (2020) serta Vanesa et al., (2020) yang mengemukakan bahwa DAR tidak 
berpengaruh terhadap harga saham.

Dengan melihat adanya faktor-faktor yang mempengaruhi harga saham, maka penulis merasa perlu menganalisa apakah profitabilitas yang diproksikan oleh ROE dan solvabilitas yang diproksikan oleh DAR berpengaruh terhadap harga saham indeks LQ45 periode 2015-2019 yang terdaftar pada Bursa Efek Indonesia.

\section{Tinjauan Pustaka}

\section{Teori Sinyal}

Menurut Brigham \& Houston (2011), teori sinyal mengemukakan tentang bagaimana pengguna laporan keuangan perusahaan menerima sinyal dan merespon atas laporan keuangan yang dipublish perusahaan. Melalui sinyal ini investor dapat menilai sebuah emiten saham mempunyai prospek yang bagus ataukah tidak, yang kemudian akan menentukan keputusannya untuk membeli saham tersebut ataukah tidak.

\section{Harga Saham}

Menurut Anoraga \& Piji (2008) harga satu saham yang diperdagangkan di pasar (bursa) adalah harga pasar dari saham yang bersangkutan. Harga pasar merupakan harga dari suatu saham pada pasar yang sedang berlangsung atau jika pasar sudah ditutup, maka harga pasar adalah harga penutupannya (closing price).

Sartono (2008) menyatakan bahwa Permintaan dan penawaran saham dapat membentuk harga saham di pasar modal. Sesuai dengan hukum supply and demand, bila suatu saham emiten mengalami kelebihan permintaan, maka harga saham emiten tersebut cenderung naik. Sebaliknya, apabila suatu saham emiten kelebihan penawaran, maka harga saham emiten tersebut cenderung turun. Ini artinya, pergerakan harga saham akan senantiasa diamati oleh para investor karena harga dapat berubah setiap saat.

\section{Profitabilitas}

Menurut Munawir (2010) rasio profitabilitas menunjukkan kemampuan perusahaan untuk memperoleh laba selama periode penyusunan laporan keuangan.

Return on Equity (ROE) adalah rasio yang digunakan untuk mengukur laba bersih yang diperoleh dari mengelola modal yang diinvestasikan oleh pemilik 
perusahaan. ROE diukur dengan perbandingan antara laba bersih dengan total modal (Syamsuddin, 2011).

$$
\text { Return on equity }(R O E)=\frac{\text { Laba Bersih Sesudah Pajak }}{\text { Modal Sendiri }} \times 100 \%
$$

\section{Solvabilitas}

Menurut Harahap (2007) rasio solvabilitas adalah rasio yang menunjukkan hubungan antara utang perusahaan terhadap modal atau asset.

Debt to Asset Ratio (DAR) diperoleh dengan menghitung perbandingan antara total utang dengan total aktiva. Dengan kata lain, rasio ini mengukur seberapa besar jumlah aktiva perusahaan yang dibiayai oleh hutang (Kasmir, 2014).

\section{Ivietode reneiluan}

Debt to Assets Ratio $($ DAR $)=\frac{\text { Total Utang }(\text { Debt })}{\text { Total Aktiva }(\text { Asset })} \times 100 \%$

Penelitian ini merupakan penelitian kuantitatif, yaitu metode penelitian dengan menggunakan analisis statistik (Sugiyono, 2016). Jenis penelitian yang dipakai ialah statistik deskriptif yang memberikan gambaran berupa data statistik secara sistematis sehingga tidak membentuk kesimpulan yang bersifat umum. Teknik analisa yang digunakan analisis regresi linear berganda dan menggunakan uji hipotesis yang menduga adanya pengaruh secara parsial dan simultan pada variabel bebas $(\mathrm{X})$ yaitu ROE dan DAR terhadap variabel terikat $(\mathrm{Y})$ yaitu harga saham.

Obyek yang dipilih adalah data tentang ROE, DAR dan harga saham di perusahaan yang terindeks LQ45. Pertimbangan terpilihnya obyek ini karena merupakan perusahaan yang sahamnya paling likuid di pasar modal, memiliki kapitalisasi pasar terbesar, mempunyai prospek pertumbuhan yang tinggi dengan fundamental kinerja yang baik dan secara periodik ( enam bulan sekali) dievaluasi Bank Indonesia.

Sumber data yang digunakan bersifat data sekunder berupa laporan keuangan perusahaan yang terindeks saham LQ-45 tahun 2015-2019 yang dipublikasikan dalam situs resmi Bursa Efek Indonesia www.idx.co.id beserta situs terkait $\underline{\text { www.idnfinancial.com dan www.sahamok.com. }}$ 


\subsection{Populasi dan Sampel}

Populasi dalam penelitian ini sebanyak 45 perusahaan terindeks saham LQ45 di Bursa Efek Indonesia dengan menggunakan teknik purposive sampling yaitu teknik untuk menentukan sampel dengan mengggunakan beberapa pertimbangan tertentu (Sugiyono, 2016). Kriteria yang dipertimbangkan dalam penentuan jumlah sampel dalam penelitian ini adalah perusahaan yang konsisten terindeks saham LQ45 selama 5 tahun periode penelitian yaitu tahun 2015 sampai dengan 2019 di Bursa Efek Indonesia serta mempublikasikan laporan keuangan di Bursa Efek Indonesia. Dari kriteria tersebut ditemukan sebanyak 31 sampel perusahaan ditunjukkan pada tabel 1 :

Tabel 1. Saham Terindeks LQ-45 Tahun 2015 - 2019

\begin{tabular}{|c|l|l|}
\hline NO & \multicolumn{1}{|c|}{ CODE } & \\
\hline 1 & ADRO & Adaro Energy Tbk. \\
\hline 2 & AKRA & AKR Corporindo Tbk. \\
\hline 3 & ANTM & Aneka Tambang Tbk. \\
\hline 4 & ASII & Astra Internasional Tbk. \\
\hline 5 & BBCA & Bank Central Asia Tbk. \\
\hline 6 & BBNI & Bank Negara Indonesia Tbk. \\
\hline 7 & BBRI & Bank Rakyat Indonesia Tbk. \\
\hline 8 & BBTN & Bank Tabungan Negara Tbk. \\
\hline 9 & BMRI & Bank Mandiri Tbk. \\
\hline 10 & BSDE & Bumi Serpong Damai Tbk. \\
\hline 11 & GGRM & Gudang Garam Tbk. \\
\hline 12 & HMSP & H. M. Sampoerna Tbk. \\
\hline 13 & ICBP & Indofood CBP Sukses Makmur Tbk. \\
\hline 14 & INCO & Vale Indonesia Tbk. \\
\hline 15 & INDF & Indofood Sukses Makmur Tbk. \\
\hline 16 & INTP & Indocement Tunggal Prakarsa Tbk. \\
\hline 17 & JSMR & Jasa Marga Tbk. \\
\hline 18 & KLBF & Kalbe Farma Tbk. \\
\hline 19 & LPPF & Matahari Department Store Tbk. \\
\hline 20 & MNCN & Media Nusantara Citra Tbk. \\
\hline 21 & PGAS & Perusahaan Gas Negara Tbk. \\
\hline 22 & PTBA & Bukit Asam Tbk. \\
\hline 23 & PTPP & PP Tbk. \\
\hline 24 & SCMA & Surya Citra Media Tbk. \\
\hline 25 & SMGR & Semen Indonesia Tbk. \\
\hline 26 & SRIL & Sri Rejeki Isman Tbk. \\
\hline 27 & TLKM & Telekomunikasi Indonesia Tbk. \\
\hline 28 & UNTR & United Tractors Tbk. \\
\hline & & \\
\hline
\end{tabular}




\begin{tabular}{|c|l|l|}
\hline NO & \multicolumn{1}{|c|}{ CODE } & \multicolumn{1}{c|}{ NAMA } \\
\hline 29 & UNVR & Unilever Indonesia Tbk. \\
\hline 30 & WIKA & Wijaya Karya Tbk. \\
\hline 31 & WSKT & Waskita Karya Tbk. \\
\hline
\end{tabular}

Sumber : Data diolah, 2020

Jumlah sampel penelitian seharusnya sebanyak 31 perusahaan $\times 5$ tahun $=$ 155 data sampel. Namun jumlah tersebut berubah menjadi 129 data sampel karena terdapat 26 data di outlier yang dimaksudkan untuk menghindari hasil analisis menjadi bias.

\subsection{Kerangka Penelitian dan Hipotesis}

Kerangka penelitian dapat digambarkan sebagai berikut :

Keterangan :

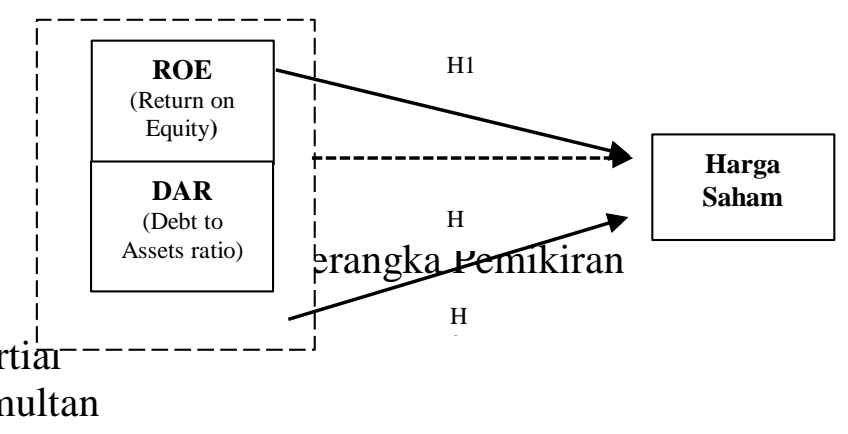

Berdasarkan teori dan beberapa hasil penelitian terdahulu mengenai pengaruh Return On Equity (ROE) dan Debt to Assets Ratio (DAR) terhadap harga saham, berikut adalah perumusan hipotesa :

H1 : Return On Equity (ROE) berpengaruh terhadap Harga Saham.

H2 : Debt to Assets Ratio (DAR) berpengaruh terhadap Harga Saham.

H3 : Return On Equity (ROE) dan Debt to Assets Ratio (DAR) berpengaruh terhadap Harga Saham.

\section{Hasil dan Pembahasan}

\subsection{Hasil Penelitian}

Tabel 2. Hasil Analisa Statistik Deskriptif

\begin{tabular}{lcrrrr}
\hline & N & \multicolumn{1}{c}{ Minimum } & \multicolumn{1}{c}{ Maximum } & \multicolumn{1}{c}{ Mean } & \multicolumn{1}{c}{ Std. Deviation } \\
\hline HARGA & 129 & 230,00 & $21.950,00$ & $5.427,8062$ & $5.069,15230$ \\
ROE & 129 & $-0,84$ & 40,78 & 14,0782 & 7,50621 \\
DAR & 129 & 0,13 & 0,92 & 0,5095 & 0,22689 \\
Valid N & 129 & & & & \\
(listwise) & & & & & \\
\hline
\end{tabular}


Sumber : Data diolah, 2020

Dari tabel 2 menunjukkan bahwa harga saham terendah sebesar 230 rupiah dimiliki oleh Sri Rejeki Isman Tbk pada tahun 2016, artinya saham Sri Rejeki Isman Tbk di tahun 2016 merupakan harga saham termurah dibandingkan dengan saham perusahaan terindeks LQ-45 lainnya. Harga saham tertinggi sebesar 21.950 rupiah dimiliki oleh Indocement Tunggal Prakarsa Tbk pada tahun 2017, artinya saham Indocement Tunggal Prakarsa Tbk di tahun 2017 merupakan saham termahal dibandingkan dengan saham perusahaan terindeks LQ-45 lainnya. Rata-rata harga saham selama periode 2015-2019 sebesar 5.427,8062 rupiah dengan simpangan baku sebesar 5.069,15230. Rata-rata harga saham yang lebih besar dari simpangan baku ini menjelaskan tidak terjadi fluktuatif data.

Profitabilitas yang diproksikan ROE pada analisa deskriptif tabel 2 diatas, nilai terendah sebesar -0,84 dimiliki oleh Vale Indonesia Tbk pada tahun 2017, artinya Vale Indonesia Tbk tidak mampu mengelola modalnya untuk menghasilkan laba. Nilai ROE tertinggi sebesar 40,78 dimiliki oleh Surya Citra Media Tbk pada tahun 2016, artinya Surya Citra Media Tbk mampu mengelola modalnya dengan baik untuk menghasilkan laba, karena untuk setiap modal Vale Indonesia Tbk mampu menghasilkan laba sebesar 40\%. Rata-rata nilai ROE selama periode 20152019 sebesar 14,0782 dengan simpangan baku sebesar 7,50621. Rata-rata nilai ROE yang lebih besar dari simpangan baku ini menjelaskan tidak terjadi fluktuatif data.

Solvabilitas yang diproksikan DAR pada analisa deskriptif tabel 2 diatas, nilai terendah sebesar 0,13 dimiliki oleh Indocement Tunggal Prakarsa Tbk pada tahun 2016, artinya Indocement Tunggal Prakarsa Tbk menggunakan asset untuk melunasi seluruh hutang perusahaan dengan sangat baik, karena total assetnya lebih besar dibandingkan dengan total hutang yang dimiliki perusahaan. Nilai tertinggi DAR sebesar 0,92 dimiliki oleh Bank Tabungan Negara Tbk pada tahun 2015, artinya Bank Tabungan Negara Tbk memiliki kecenderungan untuk berhutang, karena total hutang lebih tinggi daripada asset yang dimiliki. Rata-rata nilai DAR selama periode 2015-2019 sebesar 0,5095 dengan simpangan baku sebesar 0,22689 . Rata-rata nilai DAR yang lebih besar dari simpangan baku ini menjelaskan 
tidak terjadi fluktuatif data.

\section{Uji Normalitas}

Dari hasil output SPSS, dapat terlihat bahwa data berdistribusi secara normal dengan menggunakan metode Kolmogorov Smirnov Test. Dasar pengambilan keputusan jika 2 tailed, nilai signifikansi >0,05.

Tabel 3. Hasil Uji Normalitas

\begin{tabular}{llr}
\hline & & Unstandardized Residual \\
\hline $\mathrm{N}$ & & 129 \\
Normal Parameters & Mean & 0.0000000 \\
& Std. & 0.98386893 \\
& Deviation & \\
Most Extreme Differences & Absolute & 0.066 \\
& Positive & 0.060 \\
& Negative & -0.066 \\
Test Statistic & & 0.066 \\
Asymp. Sig. (2-tailed) & & $.200^{\mathrm{c}, \mathrm{d}}$ \\
\hline
\end{tabular}

Sumber : Data diolah, 2020

Pada Tabel 3, nilai 2-tailed significant adalah 0,200, yang berarti lebih besar dari level of significant 0,05. Artinya data variabel harga saham, ROE, dan DAR berdistribusi dengan normal.

\section{Uji Multikolinearitas}

Model regresi yang baik adalah jika tidak terjadi korelasi diantara variabel-variabel independen. Multikolinearitas dapat dilihat dari nilai tolerance dan variance inflation factor (VIF). Jika nilai tolerance $\leq 0,10$ dan VIF $\geq 10$ menunjukkan bahwa terdapat multikolinearitas, sedangkan nilai tolerance $>0,10$ dan VIF $<10$ menunjukkan bahwa tidak terdapat multikolinearitas. 
Tabel 4. Hasil Uji Multikolinearitas

Coefficients $^{\mathbf{a}}$

\begin{tabular}{|c|c|c|c|c|c|c|c|}
\hline \multirow[b]{2}{*}{ Model } & \multicolumn{2}{|c|}{$\begin{array}{c}\text { Unstandardized } \\
\text { Coefficients } \\
\text { Std. }\end{array}$} & $\begin{array}{l}\text { Standardized } \\
\text { Coefficients }\end{array}$ & \multirow[t]{2}{*}{$\mathrm{t}$} & \multirow[t]{2}{*}{ Sig. } & \multicolumn{2}{|c|}{$\begin{array}{c}\text { Collinearity } \\
\text { Statistics }\end{array}$} \\
\hline & $\mathrm{B}$ & Error & Beta & & & Tolerance & VIF \\
\hline 1 (Constant) & 7.995 & .283 & & 8.208 & .000 & & \\
\hline ROE & .007 & .012 & .056 & .621 & .536 & .991 & 1.010 \\
\hline DAR & .141 & .388 & .032 & .363 & .717 & .991 & 1.010 \\
\hline
\end{tabular}

a. Dependent Variable: LN_Y

Sumber : Data diolah, 2020

Pada Tabel 4, nilai tolerance baik ROA maupun DER adalah 0,991. Nilai VIF baik ROE maupun DAR adalah 1,010. Semua variabel tersebut memiliki nilai tolerance labih besar dari 0,10 dan Nilai VIF lebih kecil dari 10. Dapat disimpulkan semua variabel independen tidak terdapat multikolinearitas.

\section{Uji Heteroskedastisitas}

Untuk menguji apakah dalam model regresi terjadi ketidaksamaan variance dari residual satu pengamatan ke pengamatan lain, digunakan uji heteroskedastisitas. Model regresi yang baik yaitu model regresi yang tidak terdapat heteroskedastisitas. Pengujian heteroskedastisitas dapat dilakukan menggunakan uji Glejser, jika probabilitas memiliki signifikansi diatas tingkat kepercayaan 0,05 dapat disimpulkan model regresi tidak terdapat adanya heteroskedastisitas.

Tabel 5. Hasil Uji Heteroskedastisitas

Coefficients $^{\mathbf{a}}$

\begin{tabular}{|c|c|c|c|c|c|}
\hline \multirow[b]{2}{*}{ Model } & \multicolumn{2}{|c|}{$\begin{array}{c}\text { Unstandardized } \\
\text { Coefficients }\end{array}$} & \multirow{2}{*}{$\begin{array}{c}\text { Standardized } \\
\text { Coefficients } \\
\text { Beta }\end{array}$} & \multirow[b]{2}{*}{$\mathrm{t}$} & \multirow{3}{*}{$\begin{array}{l}\text { Sig. } \\
0,000\end{array}$} \\
\hline & $\mathrm{B}$ & Std. Error & & & \\
\hline 1 (Constant) & 0,983 & 0,164 & & 5,996 & \\
\hline ROE & $-0,008$ & 0,007 & $-0,103$ & $-1,157$ & 0,249 \\
\hline DAR & $-0,149$ & 0,225 & $-0,059$ & $-0,662$ & 0,509 \\
\hline
\end{tabular}

a. Dependent Variable: RES_2

Berdasarkan Tabel 5, diketahui bahwa signifikansi variabel ROE sebesar 0,249 dan 
DAR sebesar 0,509 yang berarti nilai signifikansi lebih besar dari 0,05, menunjukkan bahwa tidak terdapat gejala heteroskedastisitas pada data penelitian.

\section{Uji Autokorelasi}

Model regresi yang baik adalah regresi yang terbebas dari autokorelasi. Uji autokorelasi dapat dilakukan dengan Durbin-Watson (DW test) dimana tidak terjadi autokorelasi apabila $\mathrm{dU}<\mathrm{d}<4-\mathrm{dU}$.

Tabel 6. Hasil Uji Autokorelasi Model Summary ${ }^{\mathrm{b}}$

\begin{tabular}{ll|r|r|r|r}
\hline Model & $\mathrm{R}$ & R Square & $\begin{array}{c}\text { Adjusted R } \\
\text { Square }\end{array}$ & $\begin{array}{l}\text { Std. Error of } \\
\text { the Estimate }\end{array}$ & \multicolumn{1}{c}{$\begin{array}{c}\text { Durbin- } \\
\text { Watson }\end{array}$} \\
\hline 1 & $.062^{\mathrm{a}}$ & .004 & -.012 & .99165 & 2.129 \\
\hline
\end{tabular}

a. Predictors: (Constant), DAR, ROE

b. Dependent Variable: LN_Y

Sumber : Data diolah, 2020

Pada Tabel 6. nilai Durbin Watson (DW) adalah 2,129 dengan $\mathrm{N}=129, \mathrm{k}=2$, maka dL adalah 1,6812 dan dU adalah 1,741 (dari tabel DW dengan $\alpha=5 \%$ ). Diketahui 4- dU adalah 2,259. Dapat dikatakan data tidak terjadi autokorelasi dikarenakan nilai DW berada diantara nilai dL dan 4-dU $(1,741<2,129<2,259)$.

\section{Analisis Regresi Linear Berganda}

Analisa statistik yang digunakan dalam penelitian ini adalah analisis regresi berganda (Multiple Regression Analysis), suatu teknik yang digunakan untuk menghitung besarnya pengaruh variabel ROE dan DAR sebagai variabel independen terhadap harga saham sebagai variabel dependen.

Model persamaan regresi untuk mengetahui kemampuan profitabilitas (ROE) dan solvabilitas (DAR) dalam memprediksi harga saham adalah :

$\mathrm{Y}=7,995+0,007 \mathrm{ROE}+0.141 \mathrm{DAR}+\mathrm{e}$

Model persaman regresi menunjukkan ; (1) Konstanta sebesar 7,995 berarti jika ROE dan DAR mempunyai nilai 0, maka harga saham perusahaan yang terindeks LQ-45 di Bursa Efek Indonesia Tahun 2015-2019 akan sebesar 7,995 (2) Koefisien 
ROE pada model regresi sebesar 0,007 menunjukkan besarnya pengaruh ROE terhadap harga saham. Artinya, perubahan ROE sebesar 1 satuan (dengan asumsi variabel lainnya tetap), maka harga saham akan mengalami perubahan 0,007 (3) Koefisien DAR pada model regresi sebesar 0,141 menunjukkan besarnya pengaruh DAR terhadap harga saham. Artinya, perubahan DAR sebesar 1 satuan (dengan asumsi variabel lainnya tetap), maka harga saham akan mengalami perubahan 0,141 .

\section{Pengujian Hipotesis Parsial (Uji t)}

Berdasarkan Tabel 4, dapat dilihat hasil pengujian hipotesis secara parsial pengaruh ROE dan DAR terhadap harga saham :

1. Pengujian hipotesis secara parsial pengaruh ROE terhadap Harga Saham dengan nilai t-hitung sebesar 0,621 dan t-tabel sebesar 1,979. Karena t-hitung < t-tabel $(0,621<1,979)$ dan nilai signifikan $0,536>0,05$, maka dapat disimpulkan bahwa ROE tidak berpengaruh terhadap harga saham.

2. Pengujian hipotesis secara parsial pengaruh DAR terhadap Harga Saham dengan nilai t-hitung sebesar 0,363 dan t-tabel sebesar 1,979. Karena t-hitung < t-tabel $(0,363<1,979)$ dan nilai signifikan $0,717>0,05$, maka dapat disimpulkan bahwa DAR tidak berpengaruh terhadap harga saham.

\section{Pengujian Hipotesis Simultan (Uji F)}

\section{Tabel 6. Hasil Uji F}

ANOVA $^{\mathrm{a}}$

\begin{tabular}{llrrrrr}
\hline Model & \multicolumn{1}{c}{$\begin{array}{c}\text { Sum of } \\
\text { Squares }\end{array}$} & \multicolumn{1}{c}{ df } & \multicolumn{2}{c}{$\begin{array}{c}\text { Mean } \\
\text { Square }\end{array}$} & \multicolumn{1}{c}{ F } & \multicolumn{1}{c}{ Sig. } \\
\hline 1 & Regression & .471 & 2 & .235 & .239 & $.787^{\text {b }}$ \\
& Residual & 123.904 & 126 & .983 & & \\
& Total & 124.375 & 128 & & & \\
\hline
\end{tabular}

a. Dependent Variable: LN_Y

b. Predictors: (Constant), DAR, ROE

Sumber : Data diolah, 2020

Tabel 6 menunjukkan nilai $\mathrm{F}$ hitung sebesar 0,239 dengan nilai signifikan 0,787. Sedangkan nilai $F$ tabel sebesar 3,07. Karena nilai $F$ hitung lebih kecil dari $\mathrm{F}$ tabel $(0,239<3,07)$ dan nilai signifikan $0,787>0,05$, artinya $\mathrm{ROE}$ 
dan DAR secara bersama-sama tidak berpengaruh terhadap harga saham perusahaan terindeks LQ-45 di Bursa Efek Indonesia selama tahun 2015-2019.

\section{Pengujian Koefisien Determinasi $\left(\mathbf{R}^{2}\right)$}

Tabel 7. Hasil Uji Koefisien Determinasi

Model Summary

\begin{tabular}{|c|c|c|c|c|}
\hline Model & $\mathrm{R}$ & R Square & $\begin{array}{l}\text { Adjusted R } \\
\text { Square }\end{array}$ & $\begin{array}{l}\text { Std. Error of the } \\
\text { Estimate }\end{array}$ \\
\hline 1 & $.062^{a}$ & .004 & -.012 & .99165 \\
\hline
\end{tabular}

a. Predictors: (Constant), DAR, ROE

Sumber : Data diolah, 2020

Pada Tabel 7 menunjukkan R Square ( $\left.\mathrm{R}^{2}\right)$ sebesar 0,004 (0,4\%). Artinya, hanya sebesar $0,4 \%$ saja perubahan harga saham dipengaruhi oleh variasi dari dua variabel independen yaitu ROE dan DAR. Sedangkan sisanya $(100 \%-0,4 \%=$ 99,6\%) dijelaskan oleh variabel-variabel lain di luar model regresi yang digunakan dalam penelitian ini.

\subsection{Pembahasan}

\section{a. Pengaruh Profitabilitas (ROE) terhadap Harga Saham}

Berdasarkan hasil uji hipotesa, profitabilitas perusahaan (ROE) tidak berpengaruh terhadap harga saham. Dengan demikian hipotesis pertama yang menyatakan ROE berpengaruh terhadap harga saham ditolak. Return on Equity (ROE) yang menunjukkan kemampuan perusahaan dalam menghasilkan laba dari modal yang dipergunakan meskipun sering dijadikan acuan bagi investor sebelum berivestasi ke suatu saham, namun belum tentu menjamin saham tersebut dapat terus memberikan keuntungan di masa depan. Selain memperhatikan fundamental keuangan perusahaan, investor juga mempertimbangkan kondisi bisnis serta resikonya di masa depan sebelum memilih saham. Meskipun kinerja keuangan sebuah perusahaan baik dengan laba yang tinggi, namun bila jenis usahanya mempunyai resiko bisnis di masa depan, maka investor dapat membatalkan niatnya berinvestasi pada emiten tersebut. Laba yang tinggi belum 
tentu mengakibatkan saham emiten tersebut diminati investor dan belum tentu menjadikan harga saham emiten naik karena tidak memberikan keuntungan bagi investor pada masa mendatang.

Beberapa emiten saham indeks LQ45 di Bursa Efek Indonesia selama periode penelitian yang mempunyai ROE yang tinggi yaitu saham PT Surya Citra Media Tbk (SCMA) dengan tingkat ROE 40,78\% harga saham penutupan senilai Rp. 2.800,- di tahun 2016. Selain itu saham PT HM Sampoerna Tbk (HMSP) dengan tingkat ROE 38,46\%, harga saham penutupan senilai Rp. 2.100,- di tahun 2018. Sedangkan emiten saham indeks LQ45 di Bursa Efek Indonesia selama periode penelitian yang mempunyai ROE yang rendah yaitu PT.Vale Indonesia Tbk. (INCO) dengan tingkat ROE hanya $0,1 \%$ namun harga saham penutupan mampu mencapai Rp. 2.820,- di tahun 2016.

Hal ini dapat dianalisa bahwa meskipun PT Surya Citra Media Tbk (SCMA) dan PT HM Sampoerna Tbk (HMSP) memiliki ROE yang tinggi dibandingkan saham-saham lainnya, namun harga sahamnya masih kalah dengan saham PT.Vale Indonesia Tbk. (INCO) yang tingkat ROE nya lebih rendah karena investor selain memperhatikan ROE sebagai fundamental keuangan perusahaan juga akan mempertimbangkan kondisi bisnis sebelum memilih saham yang akan dibeli. Meskipun industri media cukup menarik, namun kehadiran digital marketing dapat mengancam industri televisi sehingga omset pemasangan iklan di televisi semakin berkurang. Begitu juga saham PT HM Sampoerna Tbk (HMSP) dianggap memiliki resiko bisnis dimasa yang akan datang karena masyarakat semakin sadar bahaya merokok didukung banyaknya larangan merokok di public area dapat membatalkan niat berinvestasi pada saham emiten ini.

Hasil penelitian ini didukung oleh penelitian Putri (2018), Vanesa et al., (2020), serta Saputri \& Arilyn (2020) yang mengemukakan bahwa ROE tidak berpengaruh terhadap harga saham. Namun hasil penelitian ini tidak sejalan dengan hasil penelitian Anindita (2017), Ridwan \& Diyani (2018), serta Firdausia \& Ariyanto (2018) menyatakan bahwa ROE berpengaruh signifikan terhadap harga saham. 


\section{b. Pengaruh Solvabilitas (DAR) terhadap Harga Saham}

Berdasarkan hasil uji hipotesa, DAR tidak berpengaruh terhadap harga saham. Dengan demikian hipotesis kedua yang menyatakan Debt to Assets Ratio (DAR) berpengaruh terhadap harga saham tidak dapat diterima. Debt to Assets Ratio (DAR) mengukur seberapa besar aktiva perusahaan dapat membayar hutang yang dimiliki perusahaan tersebut. DAR diperoleh dari rasio antara utang dengan total aktiva.

Apabila rasio Debt to Asset Ratio (DAR) tinggi, jumlah aktiva perusahaan yang dibiayai oleh hutang semakin tinggi, maka semakin sulit bagi perusahaan untuk mendapatkan tambahan utang karena dikhawatirkan perusahaan tidak mampu menutupi utang-utangnya dengan aktiva lancar yang dimilikinya. Sebaliknya bila rasionya rendah, semakin kecil perusahaan dibiayai dengan utang (Kasmir, 2014).

Emiten saham yang mempunyai nilai DAR tinggi dapat dikatakan dalam keadaan yang buruk, sehingga hal ini dapat mempengaruhi tinggi rendahnya harga saham. Teori tersebut menunjukkan hubungan yang berbeda antara Debt to Asset Ratio (DAR) terhadap harga saham dalam penelitian ini. Jika nilai Debt to Asset Ratio (DAR) perusahaan tinggi, pendanaan asset dibiayai oleh utang menjadi banyak, artinya perusahaan memiliki resiko yang tinggi. Hal ini tidak selamanya mempengaruhi harga saham menjadi rendah. Begitupun sebaliknya, jika Debt to Asset Ratio (DAR) rendah, pendanaan asset dibiayai oleh utang menjadi sedikit, sehingga perusahaan memiliki resiko yang kecil. Hal ini tidak selamanya mempengaruhi harga saham menjadi tinggi, karena masih banyak variabel lain yang mempengaruhi tinggi rendahnya harga saham.

Hasil penelitian ini didukung oleh hasil penelitian Anindita (2017), Putri (2018), Ridwan \& Diyani (2018), Nehe (2019), Sitompul (2020) serta Vanesa et al., (2020) yang mengemukakan bahwa DAR tidak berpengaruh terhadap harga saham. Namun hasil penelitian ini berbeda dengan penelitian Firdausia \& Ariyanto (2018), Ramadhana \& Sjahruddin (2018), serta Ilman (2019) menunjukkan bahwa DAR berpengaruh positif terhadap harga saham. 


\section{c. Pengaruh Profitabilitas (ROE) dan Solvabilitas (DAR) secara simultan terhadap Harga Saham}

Profitabilitas (ROE) dan Solvabilitas (DAR) secara bersama-sama tidak mempunyai pengaruh terhadap harga saham perusahaan terindeks LQ-45 yang terdaftar di Bursa Efek Indonesia Tahun 2015-2019. Ini berarti bahwa adanya kenaikan nilai ROE dan DAR tidak berpengaruh terhadap naik turunnya harga saham emiten terindeks LQ-45 selama tahun 2015-2019, begitu juga sebaliknya adanya penurunan nilai ROE dan DAR tidak berpengaruh terhadap naik turunnya harga saham emiten terindeks LQ-45 selama tahun 2015-2019. Investor lebih memperhatikan informasi dari luar yang bersifat teknikal daripada melihat kinerja keuangan perusahaan dalam laporan keuangan perusahaan.

Menurut Syamsir (2006) analisis teknikal beranggapan bahwa harga sangat ditentukan oleh keseimbangan antara supply dan demand. Jika terjadi ekses supply yaitu kelebihan supply atas demand, maka harga akan jatuh dan demikian sebaliknya. Ini berarti bahwa jika jumlah permintaan suatu saham lebih banyak daripada penawarannya, maka harga saham akan cenderung mengalami kenaikan harga. Dalam berinvestasi, investor lebih memperhatikan trend pergerakan harga saham di masa lalu, karena dianggap lebih mudah melakukan analisis dan cepat dalam pengambilan keputusan. Investor beranggapan harga pasar suatu saham ditentukan oleh kekuatan permintaan dan penawaran saham tersebut di pasar modal.

Hasil yang diperoleh dalam penelitian ini menunjukkan adanya perbedaan dengan hasil penelitian Sadewo (2018) menyatakan bahwa Profitabilitas (ROE) dan Solvabilitas (DAR) secara bersama-sama berpengaruh terhadap harga saham.

\section{Kesimpulan}

\subsection{Kesimpulan}

Hasil pengujian hipotesis dengan menggunakan analisis regresi linier berganda dengan dua variabel independen (profitabilitas dan solvabilitas) dan satu variabel dependen (harga saham) menunjukkan bahwa :

a. Profitabilitas (ROE) tidak berpengaruh terhadap harga saham perusahaan terindeks LQ-45 yang terdaftar di Bursa Efek Indonesia periode 2015-2019. 
Semakin tinggi atau rendahnya tingkat profitabilitas (ROE) tidak berpengaruh terhadap semakin tinggi atau rendahnya harga saham perusahaan tersebut.

b. Solvabilitas (DAR) tidak berpengaruh terhadap harga saham perusahaan terindeks LQ-45 yang terdaftar di Bursa Efek Indonesia periode 2015-2019. Semakin tinggi atau rendahnya tingkat solvabilitas (DAR) tidak berpengaruh terhadap semakin tinggi atau rendahnya harga saham perusahaan tersebut.

c. Profitabilitas (ROE) dan solvabilitas (DAR) secara bersama-sama tidak mempunyai pengaruh terhadap harga saham perusahaan terindeks LQ-45 yang terdaftar di Bursa Efek Indonesia periode 2015-2019.

\subsection{Saran}

Penelitian ini diharapkan dapat bermanfaat bagi berbagai pihak, maka peneliti memberikan saran yang dapat dijadikan sebagai pertimbangan dalam penelitianpenelitian selanjutnya yaitu :

a. Penelitian selanjutnya disarankan meneliti perusahaan subsektor lainnya agar hasil penelitian dapat digeneralisasikan.

b. Penelitian selanjutnya disarankan menambah periode penelitian dengan periode yang lebih panjang agar hasil penelitian lebih akurat dan dapat memprediksi hasil penelitian untuk jangka panjang.

c. Peneliti selanjutnya disarankan menambah variabel independen lain misalnya dengan menggunakan rasio likuiditas, aktivitas, dan investasi karena sangat memungkinkan variabel lain yang tidak dimasukkan dalam penelitian ini berpengaruh terhadap harga saham perusahaan.

\section{DAFTAR PUSTAKA}

Anindita, N. P. (2017). Pengaruh CR, ROE, ROA, DAR, dan DER Terhadap Harga Saham pada Perusahaan Manufaktur yang Listing di Bursa Efek Indonesia Tahun 2011-2014. Universitas Muhammadiyah Surakarta.

Anoraga, P., \& Piji, P. (2008). Pengantar Pasar Modal. Jakarta: Rineka Cipta.

Brigham, E. F., \& Houston, J. F. (2011). Dasar-dasar Manajemen Keuangan (10th ed.). Jakarta: Salemba Empat.

Firdausia, Y. K., \& Ariyanto, B. (2018). Analisis Pengaruh Kinerja Keuangan Terhadap Harga Saham Pada Perusahaan Wholesale And Retail Trade Yang 
Terdaftar Di Bursa Efek Indonesia (BEI) Tahun 2011-2016. Majalah Ekonomi, 23(2), 305-314.

Frans Napitu, J. (2018). Pengaruh Net Profit Margin Dan price Earning Ratio Terhadap Harga Saham (Survey Pada Perusahaan Perbankan Yang Terdaftar Di Bursa Efek Indonesia Periode 2011-2015). Universitas Komputer Indonesia.

Harahap, S. S. (2007). Analisis Kritis Atas Laporan Keuangan. Jakarta: PT. Raja Grafindo Persada.

Hartono, J. (2016). Teori Portofolio dan Analisis Investasi. Yogyakarta: BPFE $U G M$.

Ilman, S. (2019). Pengaruh Return On Assets, Return On Equity, Debt To Equity Ratio Dan Debt To Assets Ratio Terhadap Harga Saham Pada Perusahaan Food And Baverages Yang Terdaftar Di Bursa Efek Indonesia (BEI) Periode 2013-2017. STKIP PGRI Sumatera Barat.

Kasmir. (2014). Analisis Laporan Keuangan. Jakarta: PT. Rajagrafindo Persada.

Munawir, S. (2010). Analisis laporan Keuangan (Keempat). Yogyakarta: Liberty.

Nehe, S. T. (2019). Pengaruh Profitabilitas, Solvabilitas dan Inflasi Terhadap Harga Saham pada Perusahaan Manufaktur Sektor Industri Barang Konsumsi yang Terdaftar di BEI Periode 2015-2017. Universitas Sumatera Utara.

Putri, P. P. (2018). Pengaruh Return On Equity (ROE), Debt To Asset Ratio (DAR) Dan Earning Per Share (EPS) Terhadap Harga Saham Pada Perusahaan Gas Negara (Persero), Tbk Periode 2013-2017. STIE Ekuitas.

Ramadhana, A. A., \& Sjahruddin, H. (2018). Pengaruh Kinerja Keuangan Terhadap Harga Saham (pp. 47-65). OSF Preprints.

Ridwan, M., \& Diyani, L. A. (2018). Pengaruh Rasio Keuangan dan Pertumbuhan Penjualan Terhadap Harga Saham. Jurnal Bisnis dan Komunikasi, 5(1).

Sadewo, M. I. (2018). Analisis Pengaruh Return On Equity Dan Debt On Asset Ratio Terhadap Harga Saham Pada Perusahaan Pertambangan Yang Terdaftar Di BEI Tahun 2013-2016. Universitas Mercu Buana Jakarta.

Saputri, F. A., \& Arilyn, E. J. (2020). Faktor-Faktor yang Mempengaruhi Harga Saham pada Perusahaan Sektor Miscellaneous Industry. Trisakti School of Management.

Sartono, A. (2008). Manajeman Keuangan Teori dan Aplikasi. (Keempat). Yogyakarta: BPFE Yogyakarta. 
Sitompul, H. P. (2020). Pengaruh Earning Per Share (EPS), Return To Equity (ROE), Debt To Equity Ratio (DER), Dan Debt To Assets Ratio (DAR) Terhadap Harga Saham Pada Perusahaan Subsektor Retail Trade Yang Terdaftar Di Bursa Efek Indonesia 2016-2017. Jurnal Administrasi dan Perkantoran Modern, 9(2), 12-18.

Sudana, I. M. (2011). Manajemen Keuangan Perusahaan Teori dan Praktek. Jakarta : Erlangga.

Sugiyono. (2016). Metode Penelitian Kuantitatif, Kualitatif dan R\&D. Bandung : PT Alfabet.

Sunariyah. (2011). Pengantar Pengetahuan Pasar Modal (Keenam). Yogyakarta: UPP STIM YKPN.

Syamsir, H. (2006). Solusi Investasi di Bursa Saham Indonesia Pendekatan Analisis Teknikal melalui Studi Kasus Riil dengan Dilengkapi Formulasi MetaStock. Jakarta: PT. Elex Media Komputindo.

Syamsuddin, L. (2011). Manajemen Keuangan Perusahaan: Konsep Aplikasi dalam Perencanaan, Pengawasan, dan Pengambilan Keputusan. Jakarta: Rajawali Pers.

Vanesa, D., Yuhelmi, Y., \& Husna, N. (2020). Pengaruh Net Profit Margin (NPM), Return On Assets (ROA), Return On Equity (ROE), Debt To Equity Ratio (DER) Dan Debt To Total Assets Ratio (DAR) Terhadap Harga Saham Pada Perusahaan Manufaktur Sektor Industri Dasar Dan Kimia Yang Terdaftar Di Bursa Efek Indonesia Periode 2012-2016. Bung Hatta University.

Wiagustini, N.L.P. (2014). Manajemen Keuangan (Pertama). Denpasar : Udayana University Press. 